\title{
SORPTION OF HEAVY METALS ON LIGNITE IMPREGNATED WITH CHITOSAN
}

\author{
Martina HAVELCOVÁ ${ }^{1)^{*}}$, Jiří MIZERA ${ }^{2)}$, Vladimír MACHOVIČ ${ }^{3)}$, Lenka BORECKÁ ${ }^{1)}$, \\ Oldřich PřIBYL ${ }^{1)}$ and Ivana KRAUSOVÁ ${ }^{2)}$
}

\author{
${ }^{1)}$ Institute of Rock Structure and Mechanics, Academy of Sciences of the Czech Republic, v.v.i., \\ V Holešovičkách 41, 18209 Prague, Czech Republic \\ 2) Nuclear Physics Institute, Academy of Sciences of the Czech Republic, Řež 130, 25068 Řez, Czech Republic \\ 3) Institute of Chemical Technology Prague, Technická 5, 16628 Praha 6, Czech Republic \\ *Corresponding author's e-mail: havelcova@irsm.cas.cz
}

(Received December 2012, accepted January 2013)

\begin{abstract}
A combined sorbent was prepared by impregnation of lignite mined in the South Moravian Coalfield, Czech Republic, with chitosan. Sorption performance of the combined sorbent and the untreated lignite was tested for $\mathrm{Co}(\mathrm{II}), \mathrm{Cu}(\mathrm{II})$, and $\mathrm{Cd}(\mathrm{II})$ in equilibrium sorption experiments with respect to $\mathrm{pH}$ and metal concentration. The amount of metal retained by the sorbent was determined by instrumental neutron activation analysis in the short time irradiation mode with epithermal neutrons. For $\mathrm{pH} \sim 5$, sorption isotherms were determined and fitted using the Langmuir and Freundlich models. The results have been compared with those obtained previously for similar combined sorbent based on naturally oxidized coal mined in the Sokolov Basin, Czech Republic. It has been shown that the effect of chitosan on sorption efficiency of the chitosan-doped coal sorbents strongly depends on solution $\mathrm{pH}$, and type of coal and metal.
\end{abstract}

KEYWORDS: lignite, chitosan, heavy metals, sorption, INAA

\section{INTRODUCTION}

Development of sorbents of toxic metals and radionuclides based on inexpensive regenerable natural sorbents with high capacity, good mechanical properties and stability for waste water treatment, groundwater remediation, and construction of active geochemical barriers has a significant consequence in technology and environmental protection. Utilization of low rank, low energetic coals for such purposes is well known. Their sorption properties are given mainly by functional groups (carboxyl and phenolic) of humic substances (HS) immobilized in situ in the organo-mineral coal matrix. Solubility of HS in basic solution and lower mechanical stability of oxidized coals limit their operational range and utilization as sorbents, namely for column dynamic processes. To reduce the deterioration of coal sorption efficiency due to leaching of soluble metal-humic complexes, possibility of stabilization of coal sorbents in neutral and basic media by their combination with chitosan in a combined sorbent has been investigated in our laboratories. Chitosan (2-amino-2deoxy-( $1 \rightarrow 4)-\beta$-D-glucopyranan) is prepared by alkali deacetylation of chitin, a major component of crab and shrimp shells, insects, and fungi mycelia, the second most abundant biopolymer next to cellulose. Thanks to its ability to bind both cations and anions, chitosan is a perspective sorbent for metals also in the form of their anionic complexes (Copello et al., 2008; Guibal, 2004; Nomanbhay and Palanisamy, 2005; Popuri et al., 2009; Rhazi et al., 2002; Varma et al., 2004). Utilization of chitosan and its derivatives in water treatment for removal of HS has also been suggested (Wan Ngah et al., 2011; Wan Ngah et al., 2008; Zhao et al., 2008), and also several reports on use of chitosan or chitin for sorption of metal cations in the presence of natural organic matter (including HS) can be found in literature (Mizera et al., 2010; Mizera et al., 2007; Rangel-Mendez et al., 2009; Yan and Bai, 2005).

To verify the existence and applicability of the synergic sorption action of HS and chitosan, sorption of $\mathrm{Cs}(\mathrm{II}), \mathrm{Co}(\mathrm{II})$ and $\mathrm{Eu}(\mathrm{II})$ on lignite mined in the Sokolov Basin, Czech Republic, and its derivatives the lignite oxidized in laboratory, and naturally oxidized brown coal (leonardite, in the Czech Republic denoted as oxihumolite) - was studied (Mizera et al., 2007). An improved sorption efficiency of the coal sorbents at neutral $\mathrm{pH}$ was obtained in mixture with chitosan, namely for oxihumolite at sorption of $\mathrm{Eu}(\mathrm{II})$ and $\mathrm{Co}(\mathrm{II})$. Chitosan prevented deterioration of the sorption ability of coal with $\mathrm{pH}$ increase probably via retaining the soluble complexes with HS leached from coal. The study of combined sorbents prepared as a simple mixtures of both components, coal and chitosan, has been continued by 
development and testing of sorbents prepared by surface covering or impregnation of coal with chitosan. Recently, sorption properties of a combined sorbent prepared by covering the Sokolov oxihumolite with chitosan have been tested by its utilization in sorption of metals $\mathrm{Co}(\mathrm{II}), \mathrm{Cu}(\mathrm{II})$, and $\mathrm{Cd}(\mathrm{II})$ (Mizera et al., 2010). The present work introduces a similar combined sorbent using as a basic component other coal sorbent - lignite mined in the South Moravian Coalfield, Czech Republic, which should be more efficient than the Sokolov coals according to our previous investigation (Havelcová et al., 2009).

\section{EXPERIMENTAL}

Lignite samples were dried, milled, and sieved to 0.3-0.5 mm. Lignite was previously characterized by proximate and ultimate analyses, multielement analysis using instrumental neutron and photon activation analyses (INAA and IPAA, respectively), and petrographic optical microscopy (Havelcová et al., 2009). The combined sorbent was prepared from the lignite by its impregnation with Fluka chitosan from its solution in oxalic acid. The impregnation procedure has been adopted from the paper by Nomanbhay and Palanisamy (2005), and slightly modified. About $5 \mathrm{~g}$ of chitosan was slowly added to $100 \mathrm{ml}$ of $10 \mathrm{wt} \%$ oxalic acid under constant stirring. The mixture was heated to $40-50{ }^{\circ} \mathrm{C}$ to facilitate mixing. At room temperature, the chitosan-oxalic acid mixture formed a viscous gel. About $50 \mathrm{ml}$ of the chitosan gel was diluted with $50 \mathrm{ml}$ of water and heated to $40-50{ }^{\circ} \mathrm{C}$. About $5 \mathrm{~g}$ of the lignite was slowly added to the diluted gel and mechanically agitated using a rotary shaker at $450 \mathrm{rpm}$ for $24 \mathrm{hrs}$ at $45^{\circ} \mathrm{C}$. The gel coated lignite was then washed with deionized water and dried at $55^{\circ} \mathrm{C}$.

The combined sorbent and both components were characterized by FTIR spectrometry and their acidobasic titration curves measured by potentiometry. For the combined sorbent and the original lignite, specific surface, volume, surface and distribution of micro-, meso-, and macropores, average pore size and porosity, and proton exchange capacity were measured. The sorption efficiency of the combined sorbent and the original oxihumolite were compared at simultaneous sorption of metals $\mathrm{Co}(\mathrm{II}), \mathrm{Cu}(\mathrm{II})$, and $\mathrm{Cd}(\mathrm{II})$ in batch equilibrium sorption experiments with respect to $\mathrm{pH}$ (2-12). Sorbents were shaken for 12 hours with solutions of the metal nitrates $\left(\mathrm{V} / \mathrm{m}=200 \mathrm{~mL} \mathrm{~g}^{-1}\right.$, á $20 \mathrm{mg} \mathrm{L}^{-1}$ of a respective metal) at an ambient temperature (24-25 ${ }^{\circ} \mathrm{C}$ ) and then separated by filtration. In the filtrate, leaching of HS (or chitosan) was checked by spectrophotometry, and equilibrium $\mathrm{pH}$ after metal cation sorption was measured. The separated sorbent was analyzed for $\mathrm{Cu}, \mathrm{Co}$, and $\mathrm{Cd}$ content by the instrumental neutron activation analysis (INAA) using short time irradiation with epithermal neutrons (i.e., in a Cd shielding). Sorbent samples were dried at ambient temperature after separation from solution after sorption. About $100 \mathrm{mg}$ aliquots of the dried used sorbents were analyzed as received packed in heat sealed polyethylene capsules. The time regime used for irradiation - decay - counting was $45 \mathrm{~s}-10 \mathrm{~min}-15 \mathrm{~min}$, respectively. Further details on the INAA analytical procedures can be found in Řanda et al. (2005). For quality control purposes, metal concentration was determined also in solution by AAS in several experiments. The agreement between the results obtained from analysis of sorbent by INAA and those obtained from analysis of solution by AAS, was satisfatory, within several percent. The sorption experiments for determination of sorption isotherms were carried out in similar way, but separately for each metal, at $\mathrm{pH} \sim 5$ (at equilibrium) and initial metal concentrations ranging from 1 to $500 \mathrm{mg} \mathrm{L}^{-1}$.

\section{RESULTS AND DISCUSSION}

As shown by structural characterization of the combined sorbent in comparison with the original coal, chitosan represents only a thin, porous network on the surface of coal, which remains a predominant component in the combined sorbent. Contrary to previously examined combined sorbent based on oxihumolite (Mizera et al., 2010), where the chitosan impregnation caused an increase in specific surface, total volume of meso- and macropores, their surface, average pore size, and porosity, and decrease in micropore volume and surface, in the lignite based combined sorbent the results are generally reverse. The above parameters slightly decreased except for micropore volume and surface, which increased in the lignite upon the impregnation with chitosan. Also contrary to the oxihumolite system, the impregnation caused decrease in the proton exchange capacity in the lignite system. Leaching of HS into solution, which was observed for oxihumolite and strongly suppressed by chitosan covering, was in lignite negligible until $\mathrm{pH} \sim 10$ even without impregnation with chitosan. The differences between the chitosan-doped sorbents based on lignite and oxihumolite may reflect the differences between the original, untreated coals. These are related to changes in geochemical, textural and petrographical characteristics of coal upon its oxidation.

However, the impregnation of coal with chitosan has a significant effect on its acidobasic and sorption properties. Results of the sorption experiments with respect to $\mathrm{pH}$ are illustrated by Figure 1. When related to the initial $\mathrm{pH}$ in the adsorbate solution, the sorption efficiency $\% \mathrm{R}$ (percentage of the initial metal concentration retained on the sorbent) at sorption of $\mathrm{Cu}$ (II) is significantly higher on the combined sorbent than on the original lignite in the entire $\mathrm{pH}$ range (210). For Co(II), the positive effect of chitosan is less pronounced and limited to a $\mathrm{pH}$ range roughly between 8 and 10. For $\mathrm{Cd}(\mathrm{II})$, the effect of chitosan is negligible or even reverse, so that the combined sorbent seems to be slightly less efficient than the 

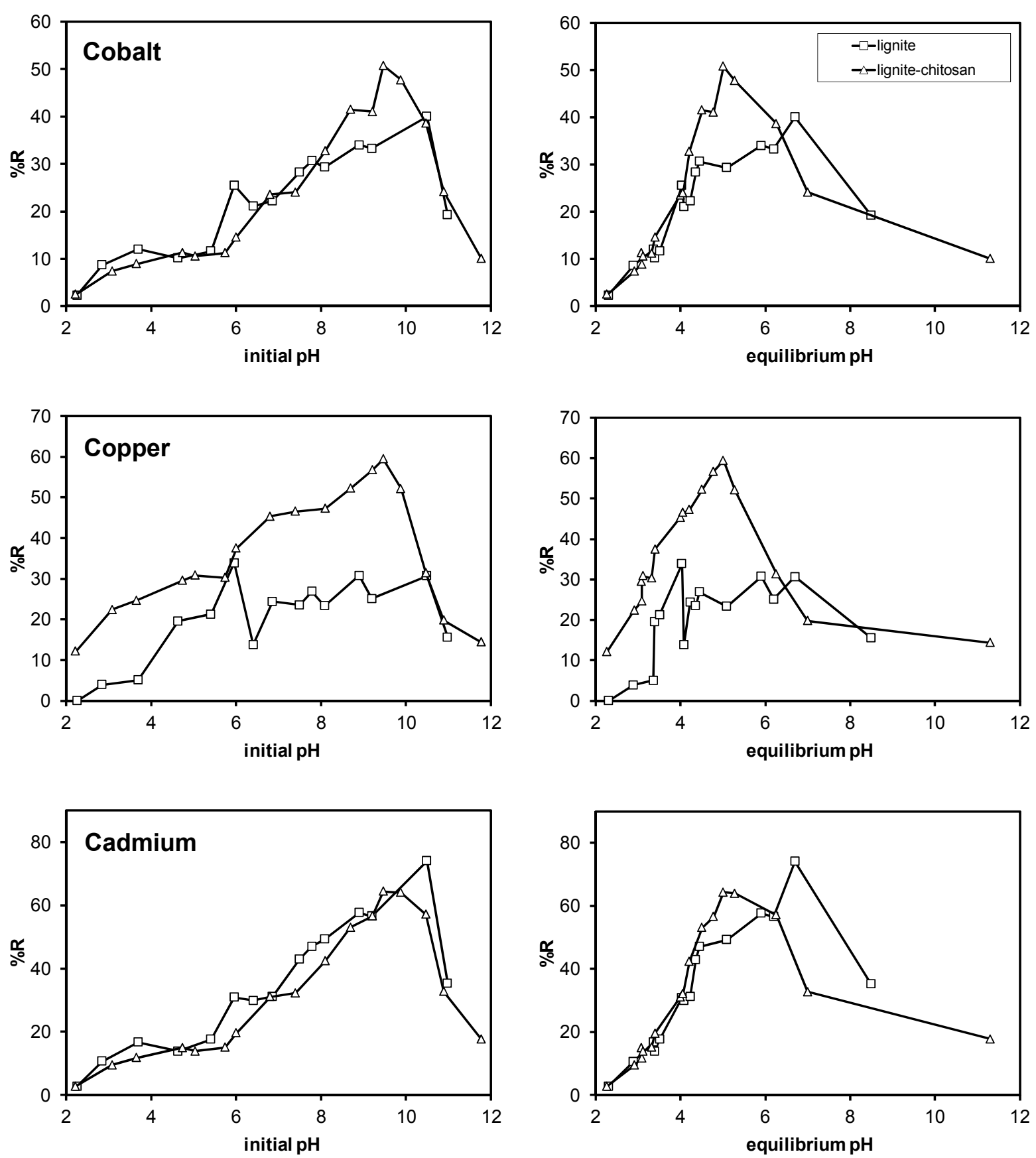

Fig. 1 Sorption efficiency as a function of initial and equilibrium $\mathrm{pH}$ in the solution at simultaneous sorption of $\mathrm{Co}(\mathrm{II}), \mathrm{Cu}(\mathrm{II})$ and $\mathrm{Cd}(\mathrm{II})$ on the combined sorbent and untreated lignite (concentration of metals á $\left.20 \mathrm{mg} \mathrm{L}^{-1}, \mathrm{~V} / \mathrm{m}=200 \mathrm{~mL} \mathrm{~g}^{-1}\right)$.

untreated lignite. In relation to the equilibrium $\mathrm{pH}$, which has been shifted from the initial $\mathrm{pH}$ to lower values due to the presence of chitosan and exchange of protons for metal cations, the positive effect of chitosan is more pronounced for $\mathrm{Co}(\mathrm{II})$, and even for $\mathrm{Cd}$ (II) a slight improvement in the sorption efficiency can be observed. This improvement of sorption efficiency is, however, confined within the $\mathrm{pH}$ range 4-6. At equilibrium $\mathrm{pH}>5, \% \mathrm{R}$ declines rapidly and becomes lower than lignite efficiency at the same $\mathrm{pH}$, even for $\mathrm{Cu}(\mathrm{II})$. Thus, besides fixing metal humates within the sorbents, chitosan may positively affect the sorption efficiency also by its buffer capacity. Advanced deprotonation of chitosan amino groups at $\mathrm{pH}>7$ obviously brings abortion of the $-\mathrm{NH}_{3}{ }^{+}$... OOC-R bonds between chitosan and the negatively charged (Mizera et al., 2005; Štamberg et al., 2003) metal-HS complexes, and the positive effect of chitosan disappears. At even higher $\mathrm{pH}$, formation of soluble metal-hydroxyl complexes $\mathrm{Cu}(\mathrm{OH})^{+}$, 

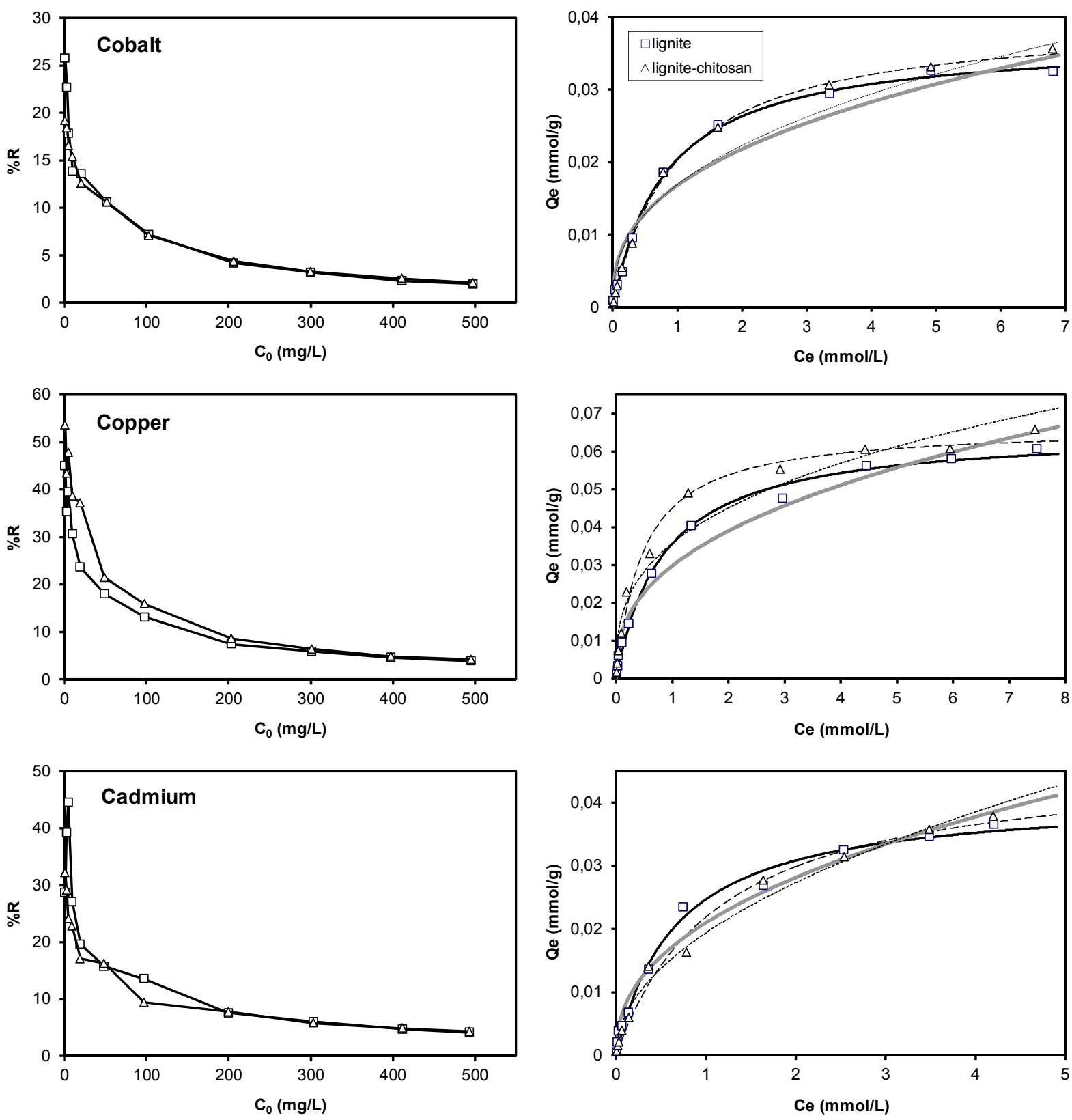

Fig. 2 Sorption efficiency as a function of initial metal concentration in solution, and Langmuir and Freundlich sorption isotherms of $\mathrm{Co}(\mathrm{II}), \mathrm{Cu}(\mathrm{II})$ and $\mathrm{Cd}(\mathrm{II})$ on the combined sorbent and untreated lignite $\left(\mathrm{V} / \mathrm{m}=200 \mathrm{~mL} \mathrm{~g}^{-1}, \mathrm{pH} \sim 5\right)$. Model curves: solid black - lignite, Langmuir; solid grey - lignite-chitosan, Freundlich; dashed - lignite-chitosan, Langmuir; dotted - lignite-chitosan, Freundlich.

$\mathrm{Cu}(\mathrm{OH})_{2}, \mathrm{Cd}(\mathrm{OH})^{+}, \mathrm{Cd}_{2}(\mathrm{OH})^{3+} \mathrm{Co}(\mathrm{OH})^{+}, \mathrm{Co}(\mathrm{OH})_{2}$, $\mathrm{Co}(\mathrm{OH})_{3}{ }^{-}$(Barnum, 1983; Pivovarov, 2005) including neutral and negatively charged species may further suppress metal retention by surface functional groups in both lignite and the lignite-chitosan combined sorbent.

In comparison with the similar experiments carried out with the oxihumolite based combined sorbent (Mizera et al., 2010), significant differences can be observed. Untreated lignite has a higher sorption efficiency than oxihumolite (the maximum $\% \mathrm{R}$ was about $20 \%$ higher for all three metals) and its deterioration in alkaline solution is slower. The positive effect of chitosan is different for individual metals. In lignite it was most pronounced for $\mathrm{Cu}(\mathrm{II})$, in oxihumolite for $\mathrm{Cd}(\mathrm{II})$.

Similar differences between lignite and oxihumolite and the combined sorbents prepared from them have been found also in evaluation of their sorption efficiency with respect to metal concentration, i.e., determination of their sorption isotherms and maximum sorption capacities. The sorption efficiencies in the dependence on the initial metal concentration and sorption isotherms are depicted in Figure 2. Langmuir isotherm has been applied, which usually takes the form 
Table 1 Parameters of Langmuir and Freundlich isotherms (see Eq. 1, Eq. 2, and Figure 2) for sorption of $\mathrm{Co}(\mathrm{II}), \mathrm{Cu}(\mathrm{II})$ and $\mathrm{Cd}(\mathrm{II})$ on the combined sorbent and untreated lignite $\left(\mathrm{V} / \mathrm{m}=200 \mathrm{~mL} \mathrm{~g}^{-1}, \mathrm{pH} \sim 5\right)$.

\begin{tabular}{llcccccc}
\hline & \multicolumn{3}{c}{ Langmuir } & \multicolumn{3}{c}{ Freundlich } \\
\cline { 2 - 8 } Metal & Sorbent & $\begin{array}{c}Q_{\max } \\
\left(\mathrm{mmol} \mathrm{g}^{-1}\right)\end{array}$ & $\begin{array}{c}K_{L F} \\
\left(\mathrm{~L} \mathrm{mmol}^{-1}\right)\end{array}$ & $\mathrm{r}^{2}$ & $\begin{array}{c}K_{F} \\
\left(\mathrm{mmol}^{1-1 / \mathrm{n}} \mathrm{L}^{1 / \mathrm{n}} \mathrm{g}^{-1}\right)\end{array}$ & & $\mathrm{r}^{2}$ \\
& & & & & & & \\
\hline $\mathrm{Co} \quad$ & lignite & 0.037 & 1.231 & 0.998 & 0.017 & 2.662 & 0.945 \\
& lignite-chitosan & 0.040 & 1.031 & 0.999 & 0.017 & 2.509 & 0.957 \\
$\mathrm{Cu}$ & lignite & 0.066 & 1.188 & 0.995 & 0.030 & 2.568 & 0.974 \\
& lignite-chitosan & 0.067 & 2.096 & 0.992 & 0.036 & 2.982 & 0.956 \\
$\mathrm{Cd}$ & lignite & 0.041 & 1.509 & 0.991 & 0.021 & 2.360 & 0.977 \\
& lignite-chitosan & 0.047 & 0.874 & 0.990 & 0.019 & 2.019 & 0.988 \\
\hline
\end{tabular}

$Q_{e}=\frac{Q_{\max } K_{L} C_{e}}{1+K_{L} C_{e}}$

where $C_{e}\left(\mathrm{mmol} \mathrm{L}^{-1}\right)$ is the equilibrium metal concentration in solution, $Q_{e}\left(\mathrm{mmol} \mathrm{g}^{-1}\right)$ is the amount of the metal adsorbed onto a sorbent at equilibrium, $Q_{\max }$ is the maximum adsorption capacity $\left(\mathrm{mmol} \mathrm{g}^{-1}\right)$ of the sorbent, $K_{L}$ is a Langmuir equilibrium constant characterizing adsorption energy $\left(\mathrm{L} \mathrm{mmol}^{-1}\right)$. Adsorption, however, is often modelled using the empirical two-parameter Freundlich isotherm, and the Freundlich equation is given by

$$
Q_{e}=K_{F} C_{e}^{1 / n}
$$

where $Q_{e}$ is the amount of retained metal at equilibrium $\left(\mathrm{mmol} \mathrm{g}^{-1}\right), C_{e}$ is the non-retained metal at equilibrium (mmol L-1), $K_{F}$ is the Freundlich constant $\left(\mathrm{mmol}^{1-1 / \mathrm{n}} \mathrm{L}^{1 / \mathrm{n}} \mathrm{g}^{-1}\right)$ and $n$ is a dimensionless parameter $(n>1)$. Larger values of $K_{F}$ and $n$ point to stronger interaction between the sorbent and metal.

The parameters of Langmuir and Freundlich isotherms for sorption of $\mathrm{Co}(\mathrm{II}), \mathrm{Cu}(\mathrm{II})$, and $\mathrm{Cd}(\mathrm{II})$ on the combined sorbent and untreated lignite are presented in Table 1. The coefficient of determination, $\mathrm{r}^{2}$, is employed to evaluate the accuracy of the model in representing the data. As seen from the graphs and $r^{2}$ values, Langmuir isotherm fits all data significantly better than Freundlich isotherm.

In comparison with our previous study of the same lignite (Havelcová et al., 2009) or with a comparable study of North Bohemian oxihumolite (Janoš et al., 2007), the adsorption capacities of both untreated lignite and the lignite covered with chitosan are significantly lower. This has been attributed to a larger grain size of the sorbent applied in the present study, resulting in lower specific surface and density of binding sites. In accord with the results observed in the $\mathrm{pH}$ dependences, the presence of chitosan enhanced the sorption efficiency only for $\mathrm{Cu}(\mathrm{II})$, whereas for $\mathrm{Co}$ (II) virtually no effect can be observed and for $\mathrm{Cd}(\mathrm{II})$ it is rather reverse (reducing sorption efficiency). From the isotherm parameters presented in Table 1, it follows that for $\mathrm{Cu}(\mathrm{II})$ the enhancement of sorption efficiency by chitosan impregnation is connected with a higher value of Langmuir constant, while the maximum adsorption capacity remains unchanged. On the other hand for $\mathrm{Co}(\mathrm{II})$ and $\mathrm{Cd}(\mathrm{II})$, the slight enhancement and reduction, respectively, of sorption efficiency by chitosan impregnation is connected with variation in both Langmuir parameters. The differences between both coals as basic components of the chitosan-doped sorbents are not quite clear, but they may reflect the above mentioned differences between the coals and also variation of sorption mechanism with the nature of metal ion (e.g., ionic radius, hardness or softness in the context of a specific interaction with functional groups of coal HS). Leaching of HS from lignite into solution is quite negligible (contrary to oxihumolite), and thus metal ions can interact only with HS on the surface and inside the coal matrix. However, their functional groups are partially occupied by chitosan binding, which restricts their availability for binding metal ions. In the case of oxihumolite with a much looser porous system, the positive effect of fixing HS by chitosan outweighs the partial reduction of availability of HS binding sites.

\section{CONCLUSION}

Combined sorbents based on low rank coals covered with chitosan were tested in sorption of $\mathrm{Co}(\mathrm{II}), \mathrm{Cu}(\mathrm{II})$, and $\mathrm{Cd}(\mathrm{II})$ with respect to $\mathrm{pH}$ and metal concentration. Impregnation of coal with chitosan has an ambiguous effect on its sorption efficiency depending on geochemical, textural and petrographical properties of individual coal type, and on competition of two opposite effects brought about by impregnation of coal with chitosan: reduction of leaching of humic substances from coal by their interaction with chitosan, and reduction of the availability of functional groups of humic substances for metal ion binding due to this interaction. 


\section{ACKNOWLEDGEMENTS}

The study was supported by the grant P108/12/G108 of the Czech Science Foundation.

\section{REFERENCES}

Barnum, D.W.: 1983, Hydrolysis of cations. Formation constants and standard free energies of formation of hydroxy complexes. Inorg. Chem. 22, 2297-230. DOI: $10.1021 / \mathrm{ic} 00158 \mathrm{a} 016$

Copello, G.J., Varela, F., Martínez-Vivot, R. and Díaz, L.E.: 2008, Immobilized chitosan as biosorbent for the removal of $\mathrm{Cd}(\mathrm{II}), \mathrm{Cr}(\mathrm{III})$ and $\mathrm{Cr}(\mathrm{VI})$ from aqueous solutions. Bioresour. Technol. 99, 6538-6544. DOI: $10.1016 / \mathrm{j}$. biortech.2007.11.055

Guibal, E.: 2004, Interactions of metal ions with chitosanbased sorbents: a review. Sep. Purif. Technol. 38, 4374. DOI: 10.1016/j.seppur.2003.10.004

Havelcová, M., Mizera, J., Sýkorová, I. and Pekař, M.: 2009 , Sorption of metal ions on lignite and the derived humic substances. J. Hazard. Mater. 161, 559-564. DOI: 10.1016/j.jhazmat.2008.03.136

Janoš, P., Sypecká, J., Mlčkovská, P., Kuráň, P. and Pilařová, V.: 2007, Removal of metal ions from aqueous solutions by sorption onto untreated low-rank coal (oxihumolite). Sep. Purif. Technol. 53, 322-329. DOI: 10.1016/j.seppur.2006.08.004

Mizera, J., Havelcová, M., Machovič, V., Borecká, L. and Krausová, I.: 2010, Sorbents of heavy metals based on combination of low rank coals and chitosan, in: $10^{\text {th }}$ International Multidisciplinary Scientific GeoConference SGEM 2010 - Conference Proceedings Volume II. STEF92 Technology Ltd., Sofia, 781-786.

Mizera, J., Mizerová, G. and Beneš, P.: 2005, Radiotracer study of europium Interaction with humic acid using electrophoresis, Ultrafiltration and Dialysis. J. Radioanal. Nucl. Chem. 263, 75-80. DOI: $10.1007 / \mathrm{s} 10967-005-0015-3$

Mizera, J., Mizerová, G., Machovič, V. and Borecká, L.: 2007, Sorption of cesium, cobalt and europium on low-rank coal and chitosan. Water Res. 41, 620-626. DOI: 10.1016/j.watres.2006.11.008

Nomanbhay, S.M. and Palanisamy, K.: 2005, Removal of heavy metal from industrial wastewater using chitosan coated oil palm shell charcoal. Electron. J. Biotechnol. $8,43-53$.

Pivovarov, S.: 2005, Modeling of ionic equilibria of trace metals $\left(\mathrm{Cu}^{2+}, \mathrm{Zn}^{2+}, \mathrm{Cd}^{2+}\right)$ in concentrated aqueous electrolyte solutions at $25^{\circ} \mathrm{C}$. J. Colloid Interface Sci. 291, 421-432. DOI: 10.1016/j.jcis.2005.05.019

Popuri, S.R., Vijaya, Y., Boddu, V.M. and Abburi, K.: 2009, Adsorptive removal of copper and nickel ions from water using chitosan coated PVC beads. Bioresour. Technol. 100, 194-199.

DOI: 10.1016/j.biortech.2008.05.041
Řanda, Z., Soukal, L. and Mizera, J.: 2005, Possibilities of the short-term thermal and epithermal neutron activation for analysis of macromycetes (mushrooms). J. Radioanal. Nucl. Chem. 264, 67-76. DOI: $10.1007 / \mathrm{s} 10967-005-0676-y$

Rangel-Mendez, J.R., Monroy-Zepeda, R., Leyva-Ramos, E., Diaz-Flores, P.E. and Shirai, K.: 2009, Chitosan selectivity for removing cadmium (II), copper (II), and lead (II) from aqueous phase: $\mathrm{pH}$ and organic matter effect. J. Hazard. Mater. 162, 503-511. DOI: 10.1016/j.jhazmat.2008.05.073

Rhazi, M., Desbrieres, J., Tolaimate, A., Rinaudo, M., Vottero, P., Alagui, A. and El Meray, M.: 2002, Influence of the nature of the metal ions on the complexation with chitosan. Application to the treatment of liquid waste. Eur. Polym. J., 38, 15231530. DOI: 10.1016/S0014-3057(02)00026-5

Štamberg, K., Beneš, P., Mizera, J., Dolanský, J., Vopálka, D. and Chalupská, K.: 2003, Modeling of metalhumate complexation based on the mean molecular weight and charge of humic substances: Application to $\mathrm{Eu}(\mathrm{III})$ humate complexes using ion exchange method. J. Radioanal. Nucl. Chem. 258, 329-345. DOI: $10.1023 / \mathrm{A}: 1026293922882$

Varma, A.J., Deshpande, S.V. and Kennedy, J.F.: 2004, Metal complexation by chitosan and its derivatives: a review. Carbohydr. Polym. 55, 77-93. DOI: 10.1016/j.carbpol.2003.08.005

Wan Ngah, W.S., Fatinathan, S. and Yosop, N.A.: 2011, Isotherm and kinetic studies on the adsorption of humic acid onto chitosan- $\mathrm{H}_{2} \mathrm{SO}_{4}$ beads. Desalination 272, 293-300. DOI: 10.1016/j.desal.2011.01.024

Wan Ngah, W.S., Hanafiah, M.A.K.M. and Yong, S.S.: 2008, Adsorption of humic acid from aqueous solutions on crosslinked chitosan-epichlorohydrin beads: Kinetics and isotherm studies. Colloids Surf. B 65, 18-24. DOI: 10.1016/j.colsurfb.2008.02.007

Yan, W.L. and Bai, R.B.: 2005, Adsorption of lead and humic acid on chitosan hydrogel beads. Water Res. 39, 688-698. DOI: 10.1016/j.watres.2004.11.007

Zhao, L., Luo, F., Wasikiewicz, J.M., Mitomo, H., Nagasawa, N., Yagi, T., Tamada, M. and Yoshii, F.: 2008, Adsorption of humic acid from aqueous solution onto irradiation-crosslinked carboxymethylchitosan. Bioresour. Technol. 99, 1911-1917. DOI: 10.1016/j.biortech.2007.03.030 